\title{
Effect of frequency of feeding and dietary treatment on metabolism, performance and carcass characteristics of swine
}

\author{
G. J. M. van Kempen, H. Boer, A. F. B. van der Poel and F. J. J. van Poppel \\ Department of Animal Nutrition, Agricultural University, Wageningen, \\ the Netherlands
}

Received: 27 April 1979; accepted: 13 August 1979

Key words: swine feeding, feeding frequency, feed efficiency, carcass characteristics, energy utilization, nitrogen retention

\section{Summary}

The influence of frequency of feeding and diet composition on average daily gain, efficiency of feed utilization and carcass characteristics of growing-finishing pigs was investigated.

A total of 96 pigs was used in this study. Pigs were fed once or twice a day or once every two days to a scale based on live-weight and weekly gain from $20 \mathrm{~kg}$ to slaughter at $105 \mathrm{~kg}$. Two kinds of feed of different economic as well as physiological importance were tested. One, normally used at the performance testing stations in the Netherland, the other a least-cost ration with some more by-products in it. The second feed was included because of its possible effect on rate of passage of ingesta in the first part of the alimentary tract. Pigs on this ration may reach the post-absorptive state earlier.

Three successive metabolism trials were conducted with pigs weighing on average 35,65 and $85 \mathrm{~kg}$ respectively. Blood samples were taken just before feeding at various points during the experimental period from two replicates at one time. In this way, once per pig during the experiment fasting values of non-esterified fatty acids (NEFA) were determined in the blood plasma.

Growth rate and feed efficiency were better in pigs fed once a day than in those fed twice a day by 4 and $3 \%$ respectively. NEFA values showed that pigs can be fed only once a day. Feeding pigs once every two days resulted in much inferior performance data.

An interaction between the two feeds was rarely found. The least cost ration caused a decrease in growth rate and feed efficiency but did produce thinner backfat and a higher meat percentage. For back-fat thickness a significant frequency $\times$ feed interaction was found. 


\section{Introduction}

The aim of this experiment was to study the effect of feeding intervals on the performance and metabolism of growing-finishing pigs.

Because the rate of passage of ingesta through the digestive system in pigs is slow, increasing frequency of feeding will probably have little effect; the rate of passage might be decreased by long intervals in feeding (Cromwell et al., 1965).

Although studies by Anderson et al. (1965) and Riis \& Grummer (1969) have indicated that pattern of feed intake determines the manner in which the digested feeds is metabolized and consequently may be reflected by differences in feed utilization and body composition, several trials have shown only slight differences between pigs fed only once a day instead of the usual practice of feeding twice a day (Braude, 1967).

When consumption of feed was restricted to only once daily short period (one meal) fat deposition in pigs decreased (Allen et al., 1963; Friend \& Cunningham, 1967) and there was no significant influence in over-all metabolism or carcass quality (Friend \& Cunningham, 1964, 1967). Furthermore, no influence of one meal was found on the lipogenic rate or the activity of enzymes studied in adipose tissue samples (O'Hea \& Leveille, 1969; Steele \& Frobish, 1976). Steele and Frobish concluded that a physiological need for a hyperlipogenesis is not produced by a 2 -hour feed / 22-hour fasting period in swine.

For conditions in the Netherlands Jongebreur (1967) and van Kempen et al. (1979) found little or no effect on a number of zootechnical characteristics whether pigs were fed once or twice a day. However as yet, the farmers have not paid heed to the fact that pigs can grow optimally on one feed a day. In practice two feedings a day are still common.

Therefore we will again raise the problem of feeding frequency with pigs. In setting up the experiment we decided to investigate two types of feed because earlier results from a trial at our institute (van Kempen et al., 1979) were obtained with a feed of very good quality. In this experiment we therefore used a least-cost ration as well, for we expected the more fibrous material in this feed to result in a faster rate of pasage in the first part of the alimentary tract, and an earlier postabsorptive state of the pigs.

\section{Material and methods}

\section{Design of the experiment}

Growing pigs were allotted to a feeding experiment of a randomized complete block design involving a $3 \times 2$ factorial arrangement with three feeding frequencies and two types of feed. The pigs were without feed for approximately 8 and 16, 24 and 48 hours when the pigs were fed twice a day, once a day and once in two days respectively. These systems were followed during the total growing-fattening period.

In all cases two kinds of feed were tested. The experiment was carried out with 96 pigs (crossbreds) consisting of 16 litters of 6 pigs obtained from different breed- 
Table 1. The six experimental treatments.

\begin{tabular}{llllr}
\hline Treatment & $\begin{array}{l}\text { Number of } \\
\text { pigs }\end{array}$ & $\begin{array}{l}\text { Type of } \\
\text { feed }\end{array}$ & Feeding frequency & $\begin{array}{l}\text { Amount of feed supplied } \\
\text { at feeding moment }(\mathrm{g} / \mathrm{kg} \mathrm{W0.75})\end{array}$ \\
1 & 16 & A & twice a day & 50 \\
2 & 16 & A & once a day & 100 \\
3 & 16 & A & once every 2 days & 200 \\
4 & 16 & B & twice a day & 50 \\
5 & 16 & B & once a day & 100 \\
6 & 16 & B & once every 2 days & 200 \\
\hline
\end{tabular}

ing stocks of different farms. Each litter consisted of either females or barrows and formed in this way a replicate. Each litter was allocated randomly to a unit of 6 individual pens and each pig was allocated at random to one of the six experimental treatment shown in Table 1.

The 6 treatments were carried out in an environmentally controlled pig-house with individual pens. All pens $(1.0 \mathrm{~m} \times 2.75 \mathrm{~m})$ had partly slatted floors and partly insulated concrete floors. Some wood-shavings were used. The average temperature during the experiment was $18-20{ }^{\circ} \mathrm{C}$, the average relative humidity was $70 \%$. The pigs were kept in light from $08 \mathrm{~h} 00$ till $20 \mathrm{~h} 00$.

\section{Feed and feeding method}

Before the experimental period started the pigs received a commercial starter ration. During the experiment two mixtures for fattening pigs were used, one mixture the one normally used at the performance testing stations in the Netherlands (Feed A), the other a commercial least-cost ration (Feed B). Both feeds were isocaloric and isonitrogeneous (by calculation) and differed mainly in the contents of crude fibre, crude fat and starch. The feeds were pelleted. The composition of the feeds used and the analysed or calculated content figures are given in Table 2 . All feeds were given in a dry feed trough.

The pigs were fed according to a scheme based on the expected average weight during the next week. This weight was calculated by increasing the weight at the moment of weighing by half the weight gain during the previous week. For every kilogram metabolic weight $\left(\mathrm{W}^{0.75}\right) 100 \mathrm{~g}$ of feed per day were supplied in all treatments. Water was supplied ad libitum. Feeding times were 08 h00 for all treatments and, in addition for pigs fed twice a day, $16 \mathrm{~h} 00$.

\section{Measurements and analytical techniques}

Once a week all pigs were weighed and the weekly feed intake was determined. The last weighing date was 7 days before slaughtering. Pigs with a weight above $100 \mathrm{~kg}$ were slaughtered in the next week. On the day of delivery to the slaughterhouse no feed was given. On the day before delivery the end-weight was determined. The pigs were slaughtered according to routine procedures and both the left and right side of the carcass was dissected according to commercial methods. For several reasons no carcass data were available from 6 pigs. Tested parts were 
weight of ham, shoulder, loin, back-fat, belly-fat and rest and the corresponding analysed carcass characteristics were:

- killing-out percentage (cold slaughter weight as \% of final weight);

- meat percentage (ham + loin + shoulder as $\%$ of cold slaughter weight);

- fat percentage (belly-fat + back-fat as $\%$ of cold slaughter weight);

- back-fat thickness (average value at back and loin);

- rest percentage (rest as \% of cold slaughter weight).

From ca. $30 \mathrm{~kg}$ live-weight onwards blood was taken once per pig during the experiment from each replicate at one time from the cava cranialis. Blood samples were collected in tubes with lithium heparin, in the morning before feeding on

Table 2. Formulation and composition of the feeds and the analysed or calculated content figures.

\begin{tabular}{|c|c|c|}
\hline Diet & A & B \\
\hline \multicolumn{3}{|l|}{ Ingredients (\%) } \\
\hline Maize & 39.5 & 10.54 \\
\hline Milo & 10.0 & - \\
\hline Barley & 10.0 & - \\
\hline Maize gluten feed & - & 9.0 \\
\hline Wheat middlings & 18.0 & 20.0 \\
\hline Molasses, beet & - & 4.0 \\
\hline Animal fat & - & 2.3 \\
\hline Dried beet pulp & - & 5.0 \\
\hline Tapioca pellets & - & 25.0 \\
\hline Lucerne meal & 5.0 & - \\
\hline Soya bean solv. extracted ( $44-47 \%$ C.P.) & 8.5 & 16.0 \\
\hline Tankage ( $59 \%$ C.P.) & - & 3.0 \\
\hline Fish meal ( $68 \%$ C.P.) & 4.0 & - \\
\hline Whey powder (delactosed) & 2.5 & 2.5 \\
\hline $\mathrm{CaHPO}_{4}(26 \%$ P, $20 \%$ Ca) & 0.5 & 0.6 \\
\hline Minerals/Vitamins & 2.0 & 2.0 \\
\hline Methionine & - & 0.06 \\
\hline \multicolumn{3}{|l|}{ Composition (as fed) } \\
\hline \multicolumn{3}{|l|}{ By analysis } \\
\hline Moisture (\%) & 13.13 & 12.53 \\
\hline Ash (\%) & $5.96 \pm 0.08$ & $8.76 \pm 0.42$ \\
\hline Crude protein (\%) & $15.97 \pm 0.40$ & $16.22 \pm 0.44$ \\
\hline Crude fat $(\%)$ & $3.17 \pm 0.05$ & $4.55 \pm 0.20$ \\
\hline Crude fibre (\%) & $5.19 \pm 0.27$ & $6.38 \pm 0.30$ \\
\hline Gross energy $(\mathrm{MJ} / \mathrm{kg})$ & 16.00 & 15.86 \\
\hline Digestible energy $(\mathrm{MJ} / \mathrm{kg})$ & 12.59 & 12.09 \\
\hline Metabolizable energy $(\mathrm{MJ} / \mathrm{kg})$ & 12.19 & 11.66 \\
\hline \multicolumn{3}{|l|}{ Calculated values } \\
\hline Calcium $(\%)$ & 1.035 & 1.078 \\
\hline Phosphorus (\%) & 0.773 & 0.875 \\
\hline Starch $(\%)$ & 39.6 & 29.2 \\
\hline $\mathrm{NE}_{\mathrm{f}}(\mathrm{MJ} / \mathrm{kg})$ & 9.063 & 9.067 \\
\hline
\end{tabular}




\section{FREQUENCY OF FEEDING OF PIGS}

the days the pigs in Treatment 3 or 6 received their feed. The non-esterified fatty acids (NEFA) in the bloodplasma were determined according to Regouw et al. (1971). In addition the heamatocrit value $(\mathrm{Ht})$ was determined to detect a possible dilution of the blood as a result of the experimental treatments.

A digestibility trial was carried out when the pigs weighed on average $35 \mathrm{~kg}$, and this trial was repeated when they were on average 65 and $85 \mathrm{~kg}$. Therefore 12 pigs, i.e. two litters which were two replicates from the feeding experiment (barrows), were placed in digestion cages, allowing separate collection of faeces and urine from each animal. Collecting faeces and urine for 6 days started about 4 days after the pigs were placed in the cages. Faeces and urine were preserved in formaldehyde $(4 \mathrm{ml})$ and hydrochloric acid $(100 \mathrm{ml})$ respectively and stored at $2{ }^{\circ} \mathrm{C}$. At the end of the collection period all faeces and all urine were mixed for sampling. Dry matter, nitrogen, crude fibre (CF), crude fat (DEE) and ash were analysed by standard methods (Weender analyses) in faeces and feed. Crude fat content was also determined by means of diethyl ether extraction after acid hydrolysis (DEE$\mathrm{HCl}$ ). Faecal nitrogen (Kjelldahl) and dry matter were also determined in fresh samples. For calculations the latter dry matter content of the faeces was the starting-point. Gross energy (GE) was determined in all samples by bomb calorimetry.

Average daily gain and feed efficiency data were calculated from the weekly growth and feed intake data. These data as well as the results of the blood analyses, digestibility trials and carcass dissections were analysed statistically.

Analysis of variance was made with three classifications: feeding frequency, feeding formula and litters or replicates. The two-factor interaction feeding formula $\times$ feeding frequency was calculated. A residual mean square was computed from the other two-factor interactions and the three-factor interaction. This mean square was used in computing the coefficient of variation.

The effects of feeding frequency, feeding formula and the interaction feeding formula $\times$ feeding frequency were tested by means of the $F$ test.

\section{Results}

During the whole experiment the animals had no problems consuming their feed, administered according to the scheme. Pigs that were fed once or twice a day consumed all their feed at one time. The pigs receiving their feeds only once every two days consumed almost entirely the administered feeds; if a small quantity was left, it was consumed within 10-11 hours after administration.

Data of the influence of treatments on overall performance are presented in Table 3. Analyses of variance revealed significant differences for average daily gain, efficiency of over-all feed utilization and feed intake as caused by feeding intervals, but these differences did not follow the order expected. In the total growing-finishing period pigs fed only once a day gained the most weight and had a superior feed efficiency, resulting in the lowest total feed intake in comparison with the two other groups. During the first four weeks of experimental period the pigs fed twice a day even showed les average daily gain in comparison with pigs 
Table 3. Effect of treatments on growth and feed efficiency at various points in the experimental period and total feed intake, final weight and days on experiment.

\begin{tabular}{|c|c|c|c|c|c|c|}
\hline \multirow[t]{2}{*}{ Treatment } & \multicolumn{3}{|c|}{ Feeding frequency } & \multicolumn{2}{|c|}{ Dietary treatment } & \multirow{2}{*}{$\begin{array}{l}\text { Coefficient } \\
\text { of variation }\end{array}$} \\
\hline & $\begin{array}{l}\text { twice } \\
\text { a day }\end{array}$ & $\begin{array}{l}\text { once } \\
\text { a day }\end{array}$ & $\begin{array}{l}\text { once per } \\
\text { two days }\end{array}$ & A & B & \\
\hline $\begin{array}{l}\text { Number of animals } \\
0-4 \text { weeks }\end{array}$ & 32 & 32 & 32 & 48 & 48 & \\
\hline Average daily gain (g) & 419 & 484 & 452 & 458 & 445 & 7.7 \\
\hline $\begin{array}{l}\text { Feed efficiency } \\
4-8 \text { weeks }\end{array}$ & 0.323 & 0.363 & 0.336 & 0.344 & 0.337 & 6.7 \\
\hline Average daily gain (g) & 505 & 547 & 507 & 556 & 483 & 8.1 \\
\hline $\begin{array}{l}\text { Feed efficiency } \\
8-12 \text { weeks }\end{array}$ & 0.300 & 0.313 & 0.296 & 0.319 & 0.285 & 6.5 \\
\hline Average daily gain (g) & 769 & 831 & 756 & 826 & 744 & 9.1 \\
\hline Feed efficiency & 0.357 & 0.370 & 0.343 & 0.367 & 0.346 & 8.3 \\
\hline After 12 weeks & & & & & & \\
\hline Average daily gain (g) & 979 & 954 & 893 & 964 & 920 & 28.3 \\
\hline Feed efficiency & 0.340 & 0.330 & 0.317 & 0.333 & 0.325 & 27.6 \\
\hline Total period & & & & & & \\
\hline Average daily gain (g) & 650 & 677 & 638 & 670 & 640 & 3.5 \\
\hline Feed efficiency & 0.340 & 0.351 & 0.331 & 0.349 & 0.332 & 2.4 \\
\hline Feed consumption $(\mathrm{kg})$ & 249 & 240 & 255 & 242 & 254 & 5.8 \\
\hline Final weight (kg) & 110 & 108 & 109 & 110 & 109 & 2.4 \\
\hline Days on experiment & 131 & 125 & 131 & 126 & 132 & 5.5 \\
\hline
\end{tabular}

fed only once every two days. However, these groups gave similar results for average daily gain and feed efficiency in the following 8 weeks of growth. After 12 weeks we observed a significant differance in growth and feed efficiency for the pigs that were fed twice a day; feeding twice a day was even better than feeding once daily.

There was also a definite difference between results noted at various points during the experiment for the dietary treatments. Pigs receiving Feed A gained $4.7 \%$ more than the least-cost ration groups. Average weight data of pigs on both dietary treatments are given in Fig. 1. This graph shows that up to 4 weeks of growth average weight curves are identical. After that time they slowly diverge up till 10 weeks, after which they parallelled with however a definite slope. The characteristics of these curves are reflected by growth data in Table 3.

Data relating to slaughter results of the treatment groups are given in Table 4. Feeding frequency influenced meat, fat and rest percentage only slightly; in fact, the only order in this respect was for fat percentage which was numerical higher with increasing feeding intervals. The difference between feeding frequencies for killing-out percentage and back-fat thickness were only statistical significant for pigs fed twice a day, with values on average $1.75 \%$ and $0.65 \mathrm{~mm}$ higher, respectively. However, response to treatments gave rise to a significant feeding frequency $X$ dietary treatment interaction: spacing the feed portions throughout a longer period gave small back-fat values for pigs that received Feed $B$ and larger values 


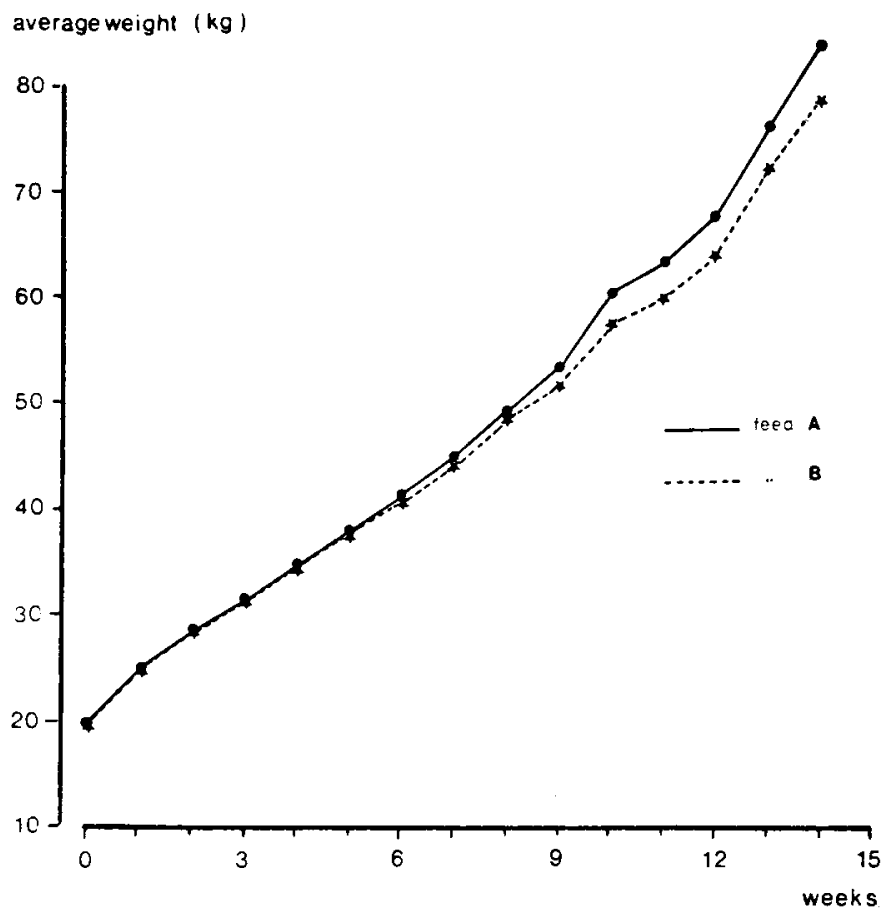

Fig. 1. Average weight data of pigs fed on Feed A and Feed B (see 'Materials and methods').

Table 4. Effect of feeding frequency and dietary treatment on slaughter results.

\begin{tabular}{|c|c|c|c|c|c|c|}
\hline \multirow[t]{2}{*}{ Treatment } & \multicolumn{3}{|c|}{ Feeding frequency } & \multicolumn{2}{|c|}{ Dietary treatment } & \multirow{2}{*}{$\begin{array}{l}\text { Coefficient } \\
\text { of variation }\end{array}$} \\
\hline & $\begin{array}{l}\text { twice } \\
\text { a day }\end{array}$ & $\begin{array}{l}\text { once } \\
\text { a day }\end{array}$ & $\begin{array}{l}\text { once per } \\
\text { two days }\end{array}$ & A & B & \\
\hline Number of animals & 29 & 30 & 31 & 46 & 44 & \\
\hline Killing-out percentage & 75.3 & 73.6 & 73.5 & 74.6 & 73.6 & 2.2 \\
\hline Average back-fat $1(\mathrm{~mm})$ & 19.2 & 18.5 & 18.6 & 19.3 & 18.1 & 14.6 \\
\hline Meat percentage & 60.0 & 60.4 & 59.7 & 59.4 & 60.7 & 2.9 \\
\hline Fat percentage & 18.1 & 18.4 & 18.7 & 18.5 & 18.3 & 7.4 \\
\hline Rest percentage & 21.9 & 21.2 & 21.6 & 22.1 & 21.0 & 9.1 \\
\hline \multicolumn{7}{|l|}{ Grading 2} \\
\hline \multirow[t]{4}{*}{ (number of animals) } & 3 & 2 & 3 & 5 & 3 & \\
\hline & 24 & 25 & 23 & 36 & 36 & \\
\hline & 1 & 3 & 5 & 5 & 4 & \\
\hline & 1 & 0 & 0 & 0 & 1 & \\
\hline
\end{tabular}

1 Interaction.

2 According to the Common Market standard.

Neth. J. agric. Sci. 27 (1979) 
Table 5. Influence of treatment on various digestion parameters and parameters of metaisulic state.

\begin{tabular}{|c|c|c|c|c|c|c|}
\hline \multirow[t]{2}{*}{ Treatment } & \multicolumn{3}{|c|}{ Feeding frequency } & \multicolumn{2}{|c|}{ Dietary treatment } & \multirow{2}{*}{$\begin{array}{l}\text { Coefficient } \\
\text { of variation }\end{array}$} \\
\hline & $\begin{array}{l}\text { twice } \\
\text { a day }\end{array}$ & $\begin{array}{l}\text { once } \\
\text { a day }\end{array}$ & $\begin{array}{l}\text { once per } \\
\text { two days }\end{array}$ & A & B & \\
\hline Haematocrit (\%) & 41.11 & 41.38 & 41.20 & 41.22 & 41.24 & 8.2 \\
\hline $\ln \mathrm{NEFA}(\mu \mathrm{mol} / \mathrm{l})$ & 3.53 & 3.58 & 4.75 & 4.11 & 4.15 & 17.7 \\
\hline Daily $\mathrm{N}$ retention (g) & 17.5 & 17.7 & 17.7 & 18.2 & 17.0 & 20.8 \\
\hline Daily $N$ retention $/ W^{0.75}(\mathrm{~g})$ & 0.80 & 0.81 & 0.84 & 0.83 & 0.81 & 16.8 \\
\hline \multicolumn{7}{|l|}{ Intake $/\left(W^{0.75} \cdot\right.$ day $)$} \\
\hline Feed $(\mathrm{g})$ & 99.4 & 97.6 & 98.3 & 98.5 & 98.3 & 1.7 \\
\hline $\mathrm{DE}(\mathrm{MJ})$ & 1.23 & 1.20 & 1.21 & 1.24 & 1.19 & 3.1 \\
\hline ME (MJ) & 1.19 & 1.16 & 1.17 & 1.20 & 1.15 & 3.3 \\
\hline $100(\mathrm{DE} / \mathrm{GE})$ & 77.8 & 77.3 & 77.2 & 78.7 & 76.2 & 2.1 \\
\hline $100(\mathrm{ME} / \mathrm{DE})$ & 96.7 & 96.8 & 96.5 & 96.8 & 96.5 & 1.4 \\
\hline \multicolumn{7}{|l|}{ Digestion coefficients } \\
\hline Organic matter $(\%)$ & 80.13 & 79.64 & 79.11 & 81.03 & 78.23 & 1.5 \\
\hline Crude protein $(\mathrm{N} \times 6.25)(\%)$ & 77.29 & 76.43 & 74.72 & 77.60 & 74.70 & 2.5 \\
\hline Crude fibre $(\%)$ & 38.20 & 37.06 & 37.04 & 35.60 & 39.26 & 10.3 \\
\hline Crude fat (DEE) (\%) & 78.66 & 78.06 & 74.72 & 75.13 & 80.13 & 2.5 \\
\hline NFE $(\%)$ & 85.89 & 85.61 & 85.41 & 86.91 & 84.37 & 1.2 \\
\hline Crude fat (DEE-HCl) (\%) & 64.60 & 64.12 & 62.92 & 62.15 & 65.61 & 4.6 \\
\hline NFE (after DEE-HCI) (\%) & 86.94 & 86.75 & 86.49 & 87.64 & 85.82 & 1.2 \\
\hline
\end{tabular}

for pigs on Feed A. Supplying Feed B produced less back-fat and resulted in a higher meat percentage and a lower rest percentage. Slaughter results showed no differences in fat percentage due to dietary treatments. Differences in grading percentages were not significant for either feeding frequency or dietary treatment.

Daily intake of feed per metabolic weight averaged $98.4 \mathrm{~g}$ and did not differ significantly between frequency treatments. Differences in the estimates for $\mathrm{N}$ retention as well as metabolizable (ME) and digestible (DE) energy intake per metabolic weight were negligible for frequency treatment, following a similar pattern to the feed intake per $\mathrm{W}^{0.75}$ (Table 5).

Estimates for the energy content of feed showed that feeding twice a day caused a non-significant better evaluation of the energy content of the feed than feeding at larger intervals. Figures were $12.40,12.32$ and $12.30 \mathrm{MJ}(\mathrm{DE})$ and $11.99,11.91$ and 11.88 $\mathrm{MJ}$ (ME) for pigs fed twice a day, once a day and once every two days respectively. The ratio of ME to DE and DE to GE did not reach statistical significance as far as feeding frequency is concerned. Dietary treatment had a significant effect on the $\mathrm{DE}$ and $\mathrm{ME}$ intake. $\mathrm{DE}$ and $\mathrm{ME}$ evaluation of both feeds were also different (Table 2). Pigs that received Feed A retained slightly more nitrogen per day, also if daily $\mathrm{N}$ retention was expressed per $\mathrm{kg}$ metabolic weight. Apparent digestibility coefficients for crude protein (CP), fat, $C F$ and nitrogen-free extract 
(NFE) decreased as feeding intervals increased. This depressing effect on nutrient digestibility was, however, only significant for $\mathrm{CP}$ as well as for crude fat and the corresponding NFE, but only when crude fat was analysed according to the direct extraction method (Weender analyses). If feed was supplied only once a day, $\mathrm{N}$ digestibility was lower than with twice daily feeding. The reverse was observed for $\mathrm{N}$ retention. Differences in digestibility coefficients due to dietary treatment were all significant. Feed B showed higher coefficients for crude fiber and for crude fat, independent of the method by which fat was analysed. If faeces were analysed by diethyl ether extraction after treatment with hydrochloric acid (DEE$\mathrm{HCl}$ ), then an apparent digestibility for fat was found 13-15 units lower than when only a diethyl ether (DEE) extraction was carried out. Because NFE was calculated from the other nutrient content figures the digestibility of NFE was somewhat higher after acid hydrolysis. The average differences between treatments were in absolute use meaningful. However, observations were based on a limited number of animals, i.e. 12 barrows.

Fasting values of plasma NEFA, transformed to the natural logarithm, showed that this parameter parallelled feeding frequency, whether or not haematocrit $(\mathrm{Ht})$ values were used as covariable. There was no significant difference in Ht values for the various treatment groups but pigs fed only once per two days did have pronounced NEFA contents in the blood in the fasting state. No differences in NEFA content were noticed between the two other groups or for dietary treatments.

\section{Discussion}

\section{Feeding frequency}

In animal husbandry it is more efficient to feed pigs only once a day to a scale based on live-weight and weekly gain; average daily gain, feed efficiency and backfat thickness were favoured more than with the usual feeding, twice a day. However, in the literature, feeding once a day is known to affect performance of pigs only slightly compared with feeding twice a day. Barber et al. (1965), Braude et al. (1963), Richter \& Antoni (1964), Cromwell et al. (1965), Richter et al. (1965), Havermann et al. (1967) and Passback et al. (1968) (partly reviewed by Braude, 1971) are but a few workers who have published findings on pigs on this topic. However, it should be emphasized that in most of these experiments pigs were kept under group-feeding conditions. Individual housing does not allow competition for feed between animals.

Half our experiment was almost identical to the experiment of van Kempen et al. (1979). The results of that experiment for growth and feed efficiency obtained with pigs who received their feed twice a day but in irregular quantities suggested that especially the periode of fasting between meals may by responsible for the unfavourable influence on growth and feed efficiency noticed in pigs fed only once per two days. Veum (1970) found that efficiency of feed utilization was the same for pigs fed ad libitum as on a 1-day feed / 1-day fast sequence but declined with increasing fasting intervals up to 2 and 3 days alternated with ad libitum feeding for 1 day. 
Fasting may elevate a lipogenic response in the pig's blood if energy requirements have to be covered from energy depots in the body. This lipolysis is reflected by an increased release of non-esterified fatty acids (NEFA) in the blood pasma and the subsequent use of these free fatty acids by the tissue of the pig may influence the efficiency of feed utilization. The results of the blood samples taken in the morning even before feeding the pigs show a significantly higher value of NEFA (InNEFA) for pigs fed once every two days; the metabolism of these pigs was apparently going through a post-absorptive state. It was observed that the fasting period for these pigs was at least 40 hours on average. Feeding pigs once a day gave similar NEFA values to feeding twice a day. Thus it may be of importance to give only one feed per day with individual feeding. So a fasting time of about 23 hours for pigs is not too long for reaching a post-absorptive state, which is in accordance with the results of O'Hea \& Leveille (1969) and Steele \& Frobish (1976) with feeding once a day. Our NEFA data confirm those reported by Riis \& Grummer (1969), van de Wal et al. (1970) and Bakke (1975).

Lack of activity in the pig house may be of importance in explaining the difference in results obtained with either group-feeding or individual feeding. We did not observe a greater energy expenditure by the more active pigs fed twice a day: frequency of feeding had no effect on coefficients for DE or ME. However, the application of the DE/ME system and the more complex net energy (NE) system may lead to differences in energy utilization as has been discussed by Sharma et al. (1973). A more reasonable explanation for the better performance of pigs fed once a day could be obtained by calculating data acording to the NE system and data of fasting heat production (FHP), because Sharma et al. found significantly different FHP values due to feeding frequency. In this respect a correlation between FHP and activity level is assumed and differences in physical activity may be responsible also for a change in energy conversion efficiency. This is of more importance when pigs fed less frequently become relatively indifferent to the excitement shown by the more frequently fed pigs. The effect of partitioning a weekly amount of feed over only 6 days in this connection thus may be different (de Wilde \& Galle, 1976).

Back-fat thickness was significantly lower for pigs fed once daily, so that, in periods of fasting, energy of endogenous source is used. According to Cunningham (1971) up to 6 hours after the meal pigs metabolized practically no energy of endogenous origin. After a 12-hour fast only one-eighth of the energy metabolized was from an endogenous source. He concluded also that the endogenous share used during the first 12 mours of fasting would have been lower when the feed level was higher. In the present experiment feed level calculated from the initial $20 \mathrm{~kg}$ to slaughter was much higher than the $1.6 \mathrm{~kg}$ used by Cunningham. In our previous experiment the same results for back-fat thickness were obtained in relation to feeding frequency as far as Feed $\mathrm{A}$ is concerned. Average values for back-fat thickness in our experiment were $18.8,18.9$ and 20.2 for pigs fed twice a day, once a day and once every two days, respectively (Feed A). However we observed a different picture for Feed B with values of $19.6,18.1$ and $16.8 \mathrm{~mm}$ respectively. Backfat thickness, meat, fat and rest percentages were mirrored by non-significant carcass grade. Differences in fill and weight of stomach and intestines which could be 
responsible for change in killing-out percentage were not examined in this experiment. Thus no statement can be made about how pigs fed les frequently will adapt to the much greater food volume.

Results of nitrogen retention and nitrogen digestibility in relation to feeding frequency are controversial since pigs fed once daily retained more nitrogen per day, although digestibility coefficient for nitrogen was slightly lower. Less muscle activity or muscle wear may explain this contradiction.

\section{Feed}

Due to some increase in the content of crude fibre, it is expected that pigs receiving Feed B would show a faster rate of passage of ingesta through the first part of the alimentary tract, resulting in a poorer digestion. In this respect the connection between passage time and digestibility of feed or feed ingredients, however, is complex because both feeds differed not only in crude fibre content but also in fat and starch. We think that in problems of this nature results cannot be interpreted with certainty as to what was simple cause or effect.

We did observe that digestibility parameters for $\mathrm{N}$, organic matter and nitrogenfree extract decreased with Feed B compared with Feed A. Furthermore the results of energy conversion showed that the pigs on Feed $\mathrm{B}$ received less metabolizable energy. These results may indicate that the metabolism of these pigs on average earlier reached the post-absorptive state. The higher NEFA content in the blood found for pigs on Feed B also supports this explanation.

Differences between dietary treatments are definitely mirrored by a significantly poorer feed efficiency for pigs on Feed B, calculated for the total experimental period. Due to the feeding schedule used in this study $\left(100 \mathrm{~g} / \mathrm{W}^{0.75}\right.$. day) differences in energy intake of pigs on Feed B may be less important at the end of the finishing period because feed intake level can then be nearly the same as ad libitum feeding. After 12 weeks of growth we could both observe a significant difference in feed efficiency between dietary treatments.

\section{Acknowledgments}

The authors wish to thank Miss G. Post for analysing feed, faeces and blood and also G. J. Noordewier for technical assistance.

\section{References}

Allen, E., C. F. Cook \& R. W. Bray, 1963. A preliminary fat deposition study of pigs fed daily, once or at multiple intervals. J. Anim. Sci. 22: 825.

Anderson, T. A., H. D. Fausch \& J. Gesler, 1965. The effect of restricted access to feed on growth rate and body composition of swine. Growth 29: 213-218.

Bakke, H., 1975. Serum levels of non-esterified fatty acids and glucose in lines of pigs selected for rate of gain and thickness of backfat. Acta Agric. scand. 25: 113-116.

Barber, R. S., R. Braude \& K. G. Mitchell, 1961. Once or twice? Pig Farming 9(3) 35.

Braude, R., 1967. The effect of changes in feeding patterns on the performance of pigs. Proc. Nutr. Soc. 26: 163. 
Braude, R., 1971. Feeding methods. In: D. J. A. Cole (Ed.), Pig production. Butterworths, London.

Braude, R., M. J. Townsend, G. Harrington \& J. G. Rowell, 1963. A comparison of feeding growing pigs once or twice daily. J. agric. Sci. 60: 389-391.

Cromwell, G. L., R. A. Pickett, J. R. Foster \& R. M. Peart, 1965. Effect of frequency of feeding on performance and carcass characteristics of swine. J. Anim. Sci. 24: 877.

Cunningham, H. M., 1971. Conversion of body fat and protein level to energy and the transfer of carbon from fatty acids to glucose in the growing pig. Can. J. Anim. Sci. 51: 341-350.

Friend, D. W. \& H. M. Cunningham, 1964. Effects of feeding frequency on metabolism, rate and efficiency of gain and on carcass quality of pigs. J. Nutr. 83: 251-256.

Friend, D. W. \& H. M. Cunningham, 1967. Growth, carcass, blood and fat studies with pigs fed once or five times daily. J. Anim. Sci. 26: 316-322.

Havermann, H., F. Schmitten \& J. Höges, 1967. Einmalige Tägliche Fütterung der Schweine in der Getreidemast. Tierzüchter No 2.

Jongebreur, A. A., 1967. Het een- en tweemaal daags voeren van mestvarkens. Scriptie, Afd. Veevoeding, Landbouwhogeschool, Wageningen.

O'Hea, E. K. \& G. A. Leveille, 1969. Influence of feeding frequency on lipogenesis and enzymatic activity of adipose tissue and on performance of pigs. J. Anim. Sci. 28: 336-341.

Passback, F. L. Jr, R. W. Rogers, B. G. Diggs \& B. Baker Jr, 1968. Effects of limited feeding on market hogs: performance and quantitative and qualitative carcass characteristics. $J$. Anim. Sci. 27: 1284-1289.

Regouw, B. I. M., P. J. Cornelissen, R. A. P. Helder, I. B. F. Spijkers \& I. M. M. Weeber, 1971. Specific determintion of free fatty acid in plasma. Clin. chim. Acta 31: 187-195.

Richter, K. \& J. Antoni, 1964. Täglich eine Futterzeit bei Schweinen in Getreidemast. Schweinezucht Schweinemast 12: 297-298.

Richter, K., K. L. Cranz \& J. Antoni, 1965. Täglich eine Futterzeit bei Schweinen in Getreidemast. Schweinezucht Schweinemast 13: 77-78.

Riis, P. M. \& R. H. Grummer, 1969. The relationship between glucose and fatty acid metabolism in pigs under various feeding conditions. Acta Agric. scand. 19: 11-17.

Sharma, V. D., L. G. Young, R. G. Brown, J. Buchanan-Smith \& G. C. Smith, 1973. Effects of frequency of feeding on energy metabolism and body composition of young pigs. Can.J. Anim. Sci. 53: 157-164.

Steele, N. C. \& L. T. Frobish, 1976. Selected lipogenic enzyme activities of swine adipose tissue as influenced by genetic phenotype, age, feeding frequency and dietary energy source. Growth 40: 369-378.

Van Kempen, G. J. M., H. Boer, G. J. Noordewier \& A. Hol, 1979. Verschillende voerfrequenties voor mestvarkens. Landbouwk. Tijdschr. 91: 19-25.

Veum, T. L., W. G. Pond, L. D. van Vleck, E. F. Walker Jr \& L. Krook, 1970. Effect of feeding-fasting intervals on finishing pigs: weight gain, feed utilisation and physical and chemical carcass measurements. J. Anim. Sci, 30: 382-387.

Wilde, R. O. de \& N. Galle, 1976. The effect of two different way of quantitative partioning of the feed on weight gain, carcass composition and serum insulin level in growing-fattening pigs. Z. Tierphysiol. Tierernähr. u. Futtermittelkde 37: 143-151.

Wal, P. G. van de, H. L. van Boxtel \& E. A. Vos, 1970. De invloed van nuchterheid op de concentratie van NEFA in het bloedplasma van varkens. Rapport No C 141, Instituut voor Veeteeltkundig Onderzoek 'Schoonoord'. Zeist, Netherlands. 